\title{
PERLINDUNGAN HUKUM TERHADAP KONSUMEN KHUSUS JASA PENUMPANG ANGKUTAN DARAT
}

\author{
Nyoman Gede Fajar Septiawan Putra, Desak Gd. Dwi Arini, Luh Putu Suryani \\ Fakultas Hukum Universitas Warmadewa, Denpasar - Bali, Indonesia
}

\begin{abstract}
Abstrak
Perlindungan Hukum ialah seluruh usaha yang menanggung adanya ketetapan hukum dalam memberikan perlindungan kepada penumpang atau konsumen yang memakai jasa dari pelaksana usaha untuk melindungi konsumen dari hal-hal yang tidak diinginkan. Angkutan Umum Online merupakan salah satu media transportasi umum yang sering dipakai oleh masyarakat umum bukan hanya untuk mengangkut penumpang tetapi membawa barang untuk diantarkan ke alamat yang dituju dengan tarif yang sudah disepakati sebelumnya. Penelitian ini bertujuan untuk menganalisis faktor-faktor yang menjadi penyebab kerugian konsumen penumpang angkutan transportasi online dan perlindungannya sesuai dengan Undang-Undang No. 8 tahun 1999 tentang Perlindungan Konsumen. Penelitian ini didesain dengan menggunakan pendektan penelitian Hukum Empiris. Teknik yang digunakan dalam mengumpulkan data yaitu teknik wawancara dilakukan pada PT Aplikasi Karya Anak Bangsa. Hasil penelitian ini menunjukan bahwa Perusahaan Angkutan Umum Online berkewajiban penuh atas kerugian yang disebabkan oleh segala orang yang dipekerjakannya dalam aktivitas angkutan umum, selain itu perusahaan angkutan umum online dan pengangkut jasa berkewajiban penuh perilah ganti kerugian yang dialami oleh konsumen dan/atau barang yang dapat mengakibatkan cacat dan/atau meninggal dunia, terkecuali diakibatkan oleh suatu peristiwa yang tidak dapat hindari atau dicegah karena kelalaian penumpang. Melalui penelitian ini diharapkan agar pihak konsumen dan pihak pengemudi jasa harus saling mengetahui peranannya masing-masing serta apa hak dan kewajiban masing-masing sehingga dapat mengurangi terjadinya kerugian bagi para konsumen ataupun pengemudi jasa angkutan Transportasi Umum Online
\end{abstract}

Kata Kunci: Angkutan Darat; Pengguna Jasa; Penyedia Jasa; Perlindungan Hukum

\begin{abstract}
Legal Protection is all businesses that bear the existence of legal provisions in providing protection to passengers or consumers who use the services of business operators to protect consumers from things that are not desirable. Public Transport Online is one of the public transportation media that is often used by the general public not only to transport passengers but to bring goods to be delivered to the destination address at a rate previously agreed. This study aims to analyze the factors that cause consumer losses for online transportation transport passengers and their protection in accordance with Law No. 8 of 1999 concerning Consumer Protection. This research was designed using the approach of Empirical Law research. The technique used in collecting data, namely the interview technique, was carried out at PT Aplikasi Karya Anak Bangsa. The results of this study indicate that the Online Public Transport Company is fully liable for losses caused by all people employed in public transport activities, besides online public transport companies and service carriers are fully obliged to sort out the compensation experienced by consumers and / or goods that can result disability and / or death, unless caused by an event that cannot be avoided or prevented due to passenger negligence. Through this research it is expected that consumers and service drivers must know each other's role and what their rights and obligations are so that it can reduce the loss for consumers or drivers of public transportation services.
\end{abstract}

Keywords: Legal Protection; Service Users; Service Providers; Transportation

\section{PENDAHULUAN}

Transportasi adalah suatu aktivitas yang sangat penting bagi kehidupan bermasyarakat di Indonesia. Pentingnya aktivitas transportasi bagi masyarakat di Indonesia karena letak wilayah geografis di Indonesia terdiri dari lautan yang luas dan pulau- pulau besar maupun kecil yang mengelilingi wilayah nusantara. Pentingnya transportasi guna menjangkau seluruh wilayah yang ada di Indonesia. 
Secara umum, aktivitas pengangkutan memegang peranan yang penting dalam 2 (dua) hal yaitu pembangunan sebagai ekonomis dan pembangunan non ekonomis. Yang dimaksud dengan pembangunan ekonomis yaitu dapat meningkatkan pendapatan berskala nasional, dapat memajukan seluruh industri nasional dan dapat menciptakan suatu lapangan pekerjaan bagi masyarakat di Indonesia. Adapun yang bersifat non ekonomis misalnya dapat memperkuat integritas bangsa Indonesia itu sendiri serta dapat meningkatkan pertahanan bagi Indonesia dan Keamanan di seluruh wilayah Indonesia. Mengingat pentingnya dan hubungannya peran Lalu Lintas dan Angkutan jalan bagi hidup masyarakat banyak di Indonesia, sehingga keperluan masyarakat secara umum di Indonesia terhadap angkutan umum merupakan pengguna aktif jasa angkutan transportasi umum perlu memperoleh prioritas yang utama beserta pelayanan secara optimal yang baik dari pemerintah Indonesia serta penyedia jasa angkutan trasportasi umum.

Diselenggarakannya lalu Lintas dan Angkutan Jalan di Indonesia perlu ditingkatkan dengan cara berkelanjutan beserta terus meningkatkan secara luas supaya jangkauan beserta pelayanan untuk masyarakat dapat merata secara menyeluruh, serta mengawasi kebutuhan masyarakat umum, kesanggupan masyarakat, kelestarian didalam lingkungan hidup serta ketertiban bagi seluruh masyarakat umum di Indonesia dalam menyelenggarakan angkutan umum.

Gerakan Perlindungan Konsumen itu sendiri muncul akibat permasalahan yang terjadi pada masyarakat sebagai konsumen beserta agresivitas produsen dalam melaksanakan aktivitas pengangkutan dan menawarkan berbagai barang dan/atau jasa tanpa dapat mengawasi etik, mutu beserta kewajiban yang kerap kali hanya dapat menguntungkan bagi pihak produsen dan mengakibatkan konflik kepada para konsumen.

Beberapa penelitian terkait dengan perlindungan hukum terhadap konsumen telah banyak diteliti oleh peneliti sebelumnya seperti Alam (2016) yang mengkaji tentang pengguna jasa angkutan umum jenis angkot di jakarta dalam perspektif hukum perlindungan konsumen. Hasilnya menunjukan bahwa selama ini pelayanan angkutan umum jenis angkot ini masih memiliki banyak kekurangan terutama menyangkut penerapan standar pelayanan minimal. Kedua Harahap (2017) menyatakan dalam penelitiannya bahwa pelaku usaha harus bertanggungjawab memberikan ganti rugi yang mungkin diderita konsumen akibat ketidakselamatan penumpang ketika ia menggunakan jasa tersebut, dapat berupa ganti rugi yang dapat berupa pengembalian uang dan atau penggantian barang. Selanjutnya, Hardi, Syamsiar, \& Nurhasanah, (2018); Muarif \& T.Haflisyah, (2018) mengkaji tentang perlindungan jasa angkutan kota. Perbedaannya dengan penelitian saat ini yaitu objek penelitian yang dilakukan di PT Aplikasi Karya Anak Bangsa. Terakhir, Fillaili (2019) mengkaji tentang tanggung jawab perusahaan transportasi online terhadap penumpang akibat adanya praktik peralihan akun driver. Hasil penelitiannya menunjukan bahwa tanggung jawab dari perusahaan penyedia transportasi terhadap kerugian yang dialami penumpang yang diangkutnya menganut prinsip tanggung jawab terbatas (limitation of liability principle).

Meski sudah ditetapkannya peraturan didalam Undang-Undang yang menjamin tentang keselamatan penumpang dan/atau konsumen dalam transportasi darat, namun kenyataannya tetap saja ada bentuk kesalahan yang terjadi didalam pelayanan yang diberikan oleh pengangkut jasa yang mengakibatkan kerugian pada konsumen itu sendiri. Keunggulan yang dimiliki dari transportasi darat adalah kemauannya melayani angkutan dari pintu ke pintu. Berdasarkan pemaparan permasalahan di atas, maka penelitian baru ini bertujuan untuk mengetahui perlindungan hukum jasa angkutan transportasi darat dan mengetahui faktor-faktor apa saja yang dapat menimbulkan kerugian bagi konsumen jasa transportasi pengangkutan darat.

\section{METODE PENELITIAN}

Dalam melakukan penelitian ini, peneliti memilih PT Aplikasi Karya Anak Bangsa sebagai lokasi yang beralamat di JL. Teuku Umar Barat No.41 Pemecutan Kelod, Kec. Denpasar Barat, Kota Denpasar, Bali 80113 sebagai lokasi penelitian. Penelitian ini didesain dengan menggunakan hukum empiris dengan pendekatan sosiologis hukum. Selanjutnya, data dikumpulkan dengan menggunakan teknik wawancara terstruktur. Pertanyaan diajukan secara lisan kepada responden. Kemudian data dianalisis dengan menggunakan teknik deskriptif yaitu menggunakan kata-kata. 


\section{HASIL PENELITIAN DAN PEMBAHASAN Perlindungan Hukum Jasa Angkutan Transportasi Darat}

Memastikan perlindungan hukum bagi seluruh masyarakat Indonesia dalam melaksanakan aktivitas ekonomi adalah satu cara yang tepat untuk dapat mengadakan ketertiban didalam masyarakat umum. Karena sering terjadinya ketidaksetaraan antara pelaku usaha dan konsumen, kedudukan konsumen biasanya dengan posisi yang lemah sehingga sering terjadi ketidakseimbangan atau ketidaksinambungan antara pelaku usaha dan konsumen, pelaku usaha seperti mempunyai kedudukan yang lebih kuat karena dapat melayani konsumen itu sendiri. Perlindungan Konsumen merupakan segenap usaha yang memastikan adanya kepastian hukum untuk memberi perlindungan kepada konsumen itu sendiri.

Perlindungan konsumen dalam Perundang-Undangan perlindungan konsumen lebih luas daripada 2 (dua) rancangan undang-undang yang lainnya. Yang pertama yaitu Rencana UndangUndang Perlindungan Konsumen yang diusulkan oleh Yayasan Lembaga Konsumen Indonesia (YLKI) yang memutuskan bahwa: Konsumen ialah pengguna barang dan/atau jasa yang terdapat dalam masyarakat, bagi kebutuhan diri sendiri atau keluarganya atau orang lain yang bukan untuk diperjual belikan Kembali. dan yang kedua menyebutkan Rencana Akademi yang disusun oleh Fakultas Hukum Universitas Indonesia yang bekerja sama dengan Departemen Perdagangan Republik Indonesia disebutkan bahwa konsumen ialah setiap orang dan/atau keluarga yang memperoleh barang untuk digunakan dan tidak untuk diperjualbelikan.

Konsumen diartikan didalam Perundang-Undangan Perlindungan Konsumen (UUPK) lebih luas dibandingkan dengan yang disebutkan diatas, karena dalam Undang-Undang Perlindungan Konsumen (UUPK) mencakupi pengguna barang dan/atau jasa untuk keperluan makhluk lainnya. Dalam hal ini mengandung maksud bahwa Undang-Undang Perindungan Konsumen (UUPK) dapat memberikan perlindungan kepada seluruh konsumen yang bukan manusia (tumbuh-tumbuhan dan hewan). Konsumen diartikan yang luas seperti ini sangatlah tepat untuk memberikan perlindungan kepada seluruh konsumen tidak terkecuali dengan hewan dan tumbuh-tumbuhan (Miru \& Yodo, 2004).

Jika hanya berpegang pada rumusan pengertian dalam Undang-Undang Perlindungan Konsumen (UUPK), lalu dikaitkan dengan Pasal 45 yang mengatur perilah gugatan ganti rugi dari konsumen untuk pelaku usaha , sehingga keluarganya, orang lain dan makhluk hidup lainnya tidak bisa menuntut ganti kerugian sebab mereka bukan termasuk konsumen, tetapi yang dialami oleh mereka dapat menjadi dasar untuk mengajukan tuntutan ganti kerugian. Jadi menurut hal diatas, jika badan hukum, keluarga dan orang lain diberikan hak untuk mengajukan ganti kerugian sehingga rumusan yang tepat pada konsumen diartikan seharusnya ditentukan bahwa konsumen ialah setiap orang dan/atau badan hukum yang mendapatkan dan/atau memakai barang dan/atau jasa yang bersumber dari pelaku usaha dan bukan untuk diperjual belikan Kembali.

Peran pengangkutan mempunyai sifat mutlak karena tanpa adanya pengangkutan perusahaan tidak akan dapat berjalan secara optimal. Sebab barang-barang yang dihasilkan oleh perusahaan atau produsen atau pabrik-pabrik atau pelaku usaha tidak sampai ditangan pedagang atau pengusaha, hanya dengan jalan pengangkutan itu pengusaha atau pedagang mendapatkan barang-barang dari pelaku usaha atau perusahaan atau pabrik-pabrik. Termasuk konsumen juga harus menggunakan jasa pengangkutan (Muhammad, 1991)

\section{Faktor Penyebab Kerugian bagi Konsumen Jasa Transportasi Pengangkutan Darat}

Ada beberap faktor yang menyebabkan kerugian bagi penumpang jasa angkutan darat dibedakan menjadi 3 (tiga) penyebab utama:

1. Pengemudi itu sendiri kemungkinan menjadi penyebab utama yang dapat membahayakan konsumen seperti:

a. Pengemudi dalam keadaan lelah atau sakit karena pengemudi itu sendiri tidak memperhatikan kondisi fisik dan selalu bekerja secara terus menerus.

b. Pengemudi melanggar larangan rambu lalu lintas yang mengatur tentang kecepatan maksimum dari kendaraan yang lewat dijalan itu sehingga akibatnya terjadi kecelakaan yang mengakibatkan kerugian pada orang atau barang yang diangkutnya. 
2. Faktor Kondisi mobil sebagai alat pengangkut wajib uji layak jalan artinya bahwa kendaraan tersebut sebelumnya dioperasikan harus diuji dulu oleh instansi teknis yang berwenang. Pengujian tersebut ada 2 (dua) tahap yaitu:

a. Uji pertama artinya pengujian yang dilakukan pada waktu kendaraan setelah proses perakitan dipabrik pembuatan mobil selesai.

b. Uji berkala, diberlakukan antara lain uji paling lama 6 (enam) bulan sekali, uji karena kecelakaan, uji karena adanya pelanggaran misalnya Gocar yang kapasitasnya melebihi batas, numpang uji dan uji mutasi artinya kendaraan yang berasal dari luar kota misalnya Bali kemudian dibawa ke daerah lain.

3. Faktor Jalan raya juga bisa menjadi penyebab utama yang menimbulkan kerugian bagi konsumen penumpang jasa Angkutan darat karena faktor jalan raya tidak dapat diabaikan begitu saja sebab jalan raya merupakan tempat beroperasinya kendaraan pengangkut tersebut juga diharapkan mempunyai kondisi yang baik bila ditinjau dari sudut pandang keamanan dan keselamatan yang lewat diatasnya.

Adapun faktor internal yang menjadi penyebab kerugian dalam pengangkutan darat, dari hasil wawancara dengan bapak Adi sebagai narasumber dari PT. Go-Jek Indonesia cabang Denpasar penyebab kerugian dari faktor internal kemungkinannya sangat kecil jika demikian adanya kerugian kemungkinan karena sistem error yang dapat menyebabkan driver tidak dapat mengakses aplikasi dan berdampak pada pelanggan atau pengguna jasa angkutan yang dapat menyebabkan pelanggan atau pengguna aplikasi Go-Jek kecewa dan merugikan pelanggan (wawancara dengan PT Go-jek, 2019).

Selain itu, adapula faktor eksternal yang menyebabkan kerugian bagi konsumen penumpang jasa angkutan transportasi darat. Dari hasil wawancara dengan berbagai responden dapat dikemukakan bahwa penyebab kerugian dalam pengangkutan darat bermacam-macam faktor. Menurut beberapa responden faktor yang utama adalah kelalaian dari pihak pengangkut yang tidak menjamin keselamatan konsumen dengan menggunakan telepon genggam pada saat berkendara ada juga yang menyebutkan bahwa adanya ketidaksiapan dari pihak pengangkut untuk melakukan pengantaran maksudnya pihak pengangkut tidak melakukan pengecekan pada kaki-kaki kendaraan, mesin kendaraan dan rem yang tidak berfungsi dengan baik sebelum melakukan pengantaran. Penumpang atau konsumen itu sendiri juga bisa menjadi penyebab kerugian dikarenakan beberapa penumpang atau konsumen meminta pihak pengangkut untuk menambah batas kecepatan berkendara agar cepat sampai ke tempat tujuan (wawancara dengan responden, 2019).

Pengangkut berkewajiban penuh memenuhi semua perihal ganti rugi yang muncul akibat kesalahan dari jasa angkutan yang dapat menyebabkan kecelakaan. Dalam keadaan seperti itu juga pada pengangkutan barang, pengangkut berkewajiban penuh perihal ganti rugi yang muncul akibat dari kelalaian yang dapat menyebabkan kerusakan pada barang yang dikirim oleh konsumen yang terjadi didalam proses angkutan sampai pembongkaran angkutan ditempat tujuan, kecuali jika adanya perjanjian yang lain. Akan tetapi, pertanggung jawaban pengangkut sangat dibatasi oleh UndangUndang pengangkutan karena yang menentukan bahwa pengangkut dapat bertanggung jawab penuh kepada seluruh akibat yang muncul karena kesalahan pengangkut, namun demikian, berhubungan dengan kerugian yang muncul akibat suasana yang memaksa, lecet pada penumpang atau barang, kekeliruan penumpang atau pengirim.

Pengangkutan yang pada umumnya ialah perpindahan tempat baik dalam berkenaan barang serta orang, sebab perpindahan itu sangat mutlak dan perlu untuk memperoleh dan meningkatkan manfaat dan meningkatkan efisiensi. Dan rangkaian dari pengangkutan itu adalah pergerakan dari tempat awal aktivitas angkutan itu dimulai ketempat tujuan sampai ditempat yang dituju maka angkutan itu akan berakhir (Soekardono, 1981).

Pertanggung jawaban pengangkutan sudah diatur didalam Undang-Undang Hukum Perdata Indonesia. Pelaku usaha sudah semestinya memenuhi ganti rugi atas biaya yang disebabkan oleh pengangkut, kerugian yang diderita oleh konsumen dan bunga yang layak di terima oleh konsumen apabila pengangkut tidak dapat memenuhi apa yang sudah diatur didalam Undang-undang Hukum Perdata Indonesia atau tidak dapat menjaga selayaknya untuk menyelamatkan barang muatan. Perjanjian Pengangkutan merupakan Perjanjian yang terjadi antara pengangkut beserta pengirim dimana pihak pengangkut mengaitkan dirinya untuk melaksanakan angkutan barang dan/atau orang dari satu tempat asal ke tempat yang dituju dengan selamat (Subekti, 1995). 
Dalam hukum pengangkutan terdapat 3 (tiga) prinsip dasar, prinsip dalam tanggung jawab atas dasar kesalahan, prinsip dalam tanggung jawab atas dasar praduga, prinsip dalam tanggung jawab penuh. Perbedaan prinsip dasar tersebut didasarkan karena pada proses pembuktian, yaitu dimana pihak mana yang harusnya membuktikan adanya menunjukan kekeliruan. Dalam pembuktian ada beberapa prinsip yang dikenal yaitu pembuktian oleh pihak yang menggugat atau pihak yang tergugat (pembuktian terbalik).

Istilah Perlindungan Konsumen mengandung aspek hukum. Oleh sebab itu, perlindungan konsumen terdapat aspek hukum. Secara umum dimana dikenal ada 4 (empat) hak-hak atau kewenangan dasar konsumen yaitu:

1. Kewenangan konsumen untuk mendapatkan ketentraman

2. Kewenangan konsumen untuk mendapatkan pemberitahuan

3. Kewenangan konsumen untuk menentukan pilihan

4. Kewenangan konsumen untuk didengar.

Dan juga berkenaan dengan kewajiban sebagai konsumen yakni:

1. Memahami dan memperhatikan dan mengerti setiap isyarat dan/atau tahap kegiatan penggunaan atau pemanfaatan barang atau jasa, demi keselamatan dan keamanan setiap konsumen

2. Bersikap baik kepada pihak pengangkut dalam melaksanakan transaksi barang dan atau jasa

3. Memenuhi tarif sesuai dengan jumlah yang disepakati sebelumnya

4. Menyertai segala proses usaha pada penyelesaian hukum secara patut (Kristiyanti, 2011)

Kewajiban pengangkut sebagai penyelenggara jasa:

1. Pengangkut diwajibkan untuk menjaga seluruh keamanan dan keselamatan penumpang/barang dari saat naik sampai dengan turun dari transportasi yang digunakan.

2. Bila mengakibatkan cedera ringan sampai dengan meninggal sehingga pihak pengangkut wajib mengganti rugi yang timbul sebabnya diderita oleh keluarga atau anak-anak yang ditinggalkan oleh penumpang itu.

3. Jika penumpang itu sendiri diangkut yang atas dasar dari perjanjian dengan pihak yang ketiga pengangkut diwajibkan baik terhadap pihak ketiga serta dengan penumpang dan ahli warisnya dengan mengindahkan Alinea-alinea yang lain didalamnya.

4. Pengangkut berkewajiban penuh atas perlakuan orang-orang yang dipekerjakannya dan barangbarang yang dipakai didalam jasa pengangkutan itu.

5. Pengangkut berkewajiban penuh atas perihal rugi yang muncul akibat keterlambatan proses pengangkutan, terkecuali pengangkut dapat memperlihatkan bukti bahwa keterlambatan tersebut dapat dicegah dan dihindari olehnya.

6. Jika situasi yang sedang berlaku setempat tidak dapat mencapai tempat yang dituju dalam waktu yang sudah ditentukan dengan seksama, maka pengangkut bertanggung jawab mengantarkan penumpang ke tempat yang dituju yang sudah ditentukan dengan transportasi lain atas biayanya sendiri.

Hak pengangkut sebagai penyelenggara jasa tidak disebutkan secara jelas dalam KUH dagang apapun yang jadi hak pengangkut dalam pengangkutan orang. Secara implisit hak-hak pengangkut dapat disimpulkan sebagai berikut:

1. Mendapat bayaran ongkos dari konsumen

2. Mengatur penumpang dalam menjaga keamanan dan keselamatan konsumen

3. Menunggu penumpang di pangkalan.

\section{SIMPULAN DAN SARAN}

1. Simpulan

Penumpang berhak mendapatkan keselamatan dan keamanan selama dalam memakai alat pengangkutan transportasi umum. Maka pelaku usaha Angkutan Umum berkewajiban atas kerugian yang timbul yang disebabkan oleh orang yang dipekerjakannya dalam aktivitas pengangkutan termasuk perihal ganti rugi atas cedera ringan sampai dengan kematian yang karenanya diderita oleh keluarga yang ditinggalkan, kecuali adanya peristiwa yang tidak dapat dihindari dan dicegah karena 
kesalahan penumpang. Dengan adanya Undang-Undang No.8 tahun 1999 tentang Perlindungan Konsumen dan Undang-Undang No.22 tahun 2009 tentang lalu Lintas dan Angkutan Jalan memberikan rasa aman dan nyaman atas keselamatan dan keamanan konsumen itu sendiri.

\section{Saran}

Melalui penelitian ini diharapkan agar pihak konsumen dan pihak pengemudi jasa harus saling mengetahui peranannya masing-masing serta apa hak dan kewajiban masing-masing sehingga dapat mengurangi terjadinya kerugian bagi para konsumen ataupun pengemudi jasa angkutan Transportasi Umum Online.

\section{DAFTAR PUSTAKA}

Alam, F. S. (2016). Pengguna Jasa Angkutan Umum Jenis Angkot Di Jakarta Dalam Perspektif Hukum Perlindungan Konsumen. SALAM: Jurnal Sosial Dan Budaya Syar-I, 3(2), 197-216.

Fillaili, N. (2019). Tanggung Jawab Perusahaan Transportasi Online Terhadap Penumpang Akibat Adanya Praktik Peralihan Akun Driver. Jurist-Diction, 2(4), 1375-1404.

Harahap, R. (2017). Aspek Hukum Perlindungan Terhadap Penumpang Bus Dalam Mewujudkan Perlindungan Konsumen. De Lega Lata, 1(1), 211-233.

Hardi, W., Syamsiar, R., \& Nurhasanah, S. (2018). Perlindungan Hukum Terhadap Penumpang Jasa Angkutan Ojek Online Di Bandar Lampung. Pactum Law Journal, 2(1), 505-521.

Kristiyanti, C. T. S. (2011). Hukum Perlindungan Konsumen. Jakarta: Sinar Grafika.

Miru, A., \& Yodo, S. (2004). Hukum Perlindungan Konsumen. Jakarta: PT Raja Grafindo Persada.

Muarif, \& T.Haflisyah. (2018). Perlindungan Konsumen terhadap Penumpang Angkutan Kota LabiLabi di Kota Banda Aceh (Suatu Penelitian di Wilayah Hukum Dinas Perhubungan Komunikasi dan Informatika Kota Banda Aceh). Jurnal Ilmiah Mahasiswa Bidang Hukum Keperdataan, 2(2), 261-273.

Muhammad, A. (1991). Hukum Pengangkutan Niaga. Bandung: PT. Citra Aditya Bakti.

Soekardono, R. (1981). Dagang Indonesia (Jilid II). Jakarta: Rajawali Pers.

Subekti, R. (1995). Aneka Perjanjian. Bandung: PT Citra Aditya Bakti. 